\title{
Seed morphology and endosperm structure of selected species of Primulaceae, Myrsinaceae, and Theophrastaceae and their systematic importance
}

\author{
Maria Morozowska • Aneta Czarna • \\ Marcin Kujawa $\cdot$ Andrzej M. Jagodzinski
}

Received: 4 February 2010/ Accepted: 4 October 2010/Published online: 11 November 2010

(C) The Author(s) 2010. This article is published with open access at Springerlink.com

\begin{abstract}
Seed size and shape, seed coat surface pattern, seed coat thickness, and endosperm structure were investigated in Androsace septentrionalis, Cortusa matthioli, Hottonia palustris, Primula elatior, Soldanella carpatica (Primulaceae), Anagallis arvensis, A. minima, Cyclamen purpurascens, Glaux maritima, Lysimachia nemorum, L. vulgaris, Trientalis europaea (Myrsinaceae), and Samolus valerandi (Theophrastaceae). Three seed size categories were distinguished on the basis of biometric measurements. Almost all seeds examined were found to be small with an angular shape classified as sectoroid or polyhedral. A new type of seed shape, suboval, was identified for H. palustris. Cyclamen purpurascens seeds differed from seeds of all other species examined because of their large size, subglobose shape, and concave hilar area. Despite the different
\end{abstract}

M. Morozowska $(\bowtie) \cdot$ A. Czarna

Department of Botany, Poznan University of Life Sciences,

Wojska Polskiego 71c, 60-625 Poznan, Poland

e-mail: mariamor@up.poznan.pl

A. Czarna

e-mail: czarna@up.poznan.pl

\section{Kujawa}

Laboratory of Electron and Confocal Microscope,

Faculty of Biology, Adam Mickiewicz University,

Umultowska 89, 61-614 Poznan, Poland

e-mail:wpmek@amu.edu.pl

A. M. Jagodzinski

Department of Forest Protection,

Poznan University of Life Sciences,

Wojska Polskiego 71c, 60-625 Poznan, Poland

e-mail: amj@man.poznan.pl

A. M. Jagodzinski

Institute of Dendrology, Polish Academy of Sciences,

Parkowa 5, 62-035 Kornik, Poland shape types, the length/width ratio of the seeds examined was constant, while their hilum length/width ratio was a highly variable feature. Three types of seed surface patterns were observed: (1) reticulate, (2) tuberculate with secondary striations, and (3) poroid-alveolate with the presence of a spongy outer layer. For seeds of Anagallis arvensis, A. minima, Cortusa matthioli, Lysimachia nemorum, and Soldanella carpatica, secondary seed sculpture was described. The seed coats of all species examined were twolayered, and great differences in testa thickness were found $(9.9-128.6 \mu \mathrm{m})$. In general, seeds of the Myrsinaceae species were more often characterized by thick testa. Different proportions in thickness of the inner and outer testa layers were observed. In seeds with reticulate seed patterns, the inner testa layer was twice to several times thicker than the outer layer, while the opposite proportions were observed in seeds with the tuberculate or poroid-alveolate seed sculpture pattern. In seeds of all species examined, oxalate crystals were present on the surface of the inner testa layer. Thus, the presence or absence of oxalate crystals in testa is not a feature distinguishing species with angular or subglobose seeds. Four types of endosperm structure were identified according to the thickness of the endosperm cell walls and the relief of their inner surface: (1) with evenly thickened and smooth cell walls, (2) with evenly thickened cell walls and circular or helical thickenings on their inside surfaces, (3) with very thick, but not evenly thickened cell walls with constrictions ("pitted"), and (4) with very thin papery and undulate cell walls. There is no rule concerning the seed shape, type of the seed sculpture, testa thickness, or endosperm structure that corresponds to the family affiliation of the species examined.

Keywords Seed morphology $\cdot$ Seed sculpture $\cdot$ Testa Endosperm structure 


\section{Introduction}

The phylogenetic relationships within the group of three families-Primulacaeae, Myrsinaceae, and Theophrastaceae-based either on DNA sequences from plastid (atpB, $n d h \mathrm{~F}, r b c \mathrm{~L}$, and $t r n \mathrm{~L}-\mathrm{F}$ ), nuclear (ITS), and mitochondrial (atp1 and matR) genes or morphological data have been analyzed in many papers (Anderberg and Ståhl 1995; Anderberg et al. 1998, 2000, 2002; Källersjö et al. 2000; Caris et al. 2000; Hao and $\mathrm{Hu}$ 2001; Mast et al. 2001; Källersjö and Ståhl 2003; Martins et al. 2003; Hao et al. 2004; Ståhl and Anderberg 2004; Manns and Anderberg 2005, 2007; Oh et al. 2008). As a result of some of these studies, strong support for a sister group relationship between Myrsinaceae s.str. and the tribe Lysimachieae of Primulaceae was found. Källersjö et al. (2000) recognized four families among the "primuloid" families of the Ericales s.l., namely Primulaceae, Myrsinaceae, Theophrastaceae, and Maesaceae. In their opinion the recognition of four families was the best way of preserving taxonomic stability but required some generic realignments. These realignments concerned Samolus, which was transferred to Theophrastaceae; Maesa, which was raised to family level; and Lysimachia, Anagallis, Trientalis, Glaux, Asterolinon, Pelletiera, Coris, Ardisiandra, and Cyclamen, which were included in Myrsinaceae. In other works on molecular phylogeny of the Primulales s.l., many close or distant relationships of certain taxa were described. Martins et al. (2003) found that Anagallis minima is rather distantly related to A. arvensis, which, along with Asterolinon and Pelletiera, is closely related to Lysimachia sect. Lerouxia. These results also supported the monophyly of a group consisting of the four genera Hottonia, Soldanella, Bryocarpum, and Omphalogramma; provided evidence against monophyly of the large genera Primula, Androsace, and Lysimachia; and showed that Cyclamen is not a member of the Myrsinaceae-Lysimachieae clade such that its position remains unclear. Hao et al. (2004) found only Glaux to be placed within Lysimachia, and Anderberg et al. (2007) suggested that in addition to Glaux, such genera as Anagallis, Asterolinon, and Pelletiera should also be nested within Lysimachia. Recent work by Oh et al. (2008) concerning seed morphology of some species from the family Myrsinaceae, especially the genus Lysimachia and a few related taxa, showed that mapping of seed characters onto a previously obtained phylogenetic tree may provide potentially synapomorphic character states for those subclades of Lysimachia that were examined. The general conclusion of these authors was that seed morphology may provide some important evidence for understanding the phylogeny of the taxa being examined.

Because the phylogenetic interrelationships within the primuloid families are still not completely resolved, we have investigated seed structure of some species of Primulaceae, Myrsinaceae, and Theophrastaceae. The aims of our study were (1) to examine and describe seed morphology and endosperm structure of some genera from Primulaceae, Myrsinaceae, and Theophrastaceae, (2) to find seed characters of systematic importance, and (3) to evaluate their usefulness in confirming or constraining a new systematic classification of the genera studied.

\section{Materials and methods}

\section{Biometric measurements}

Morphological and anatomical seed characters of Androsace septentrionalis, Cortusa matthioli, Hottonia palustris, Primula elatior, Soldanella carpatica (Primulaceae), Anagallis arvensis, A. minima, Cyclamen purpurascens, Glaux maritima, Lysimachia nemorum, L. vulgaris, Trientalis europaea (Myrsinaceae), and Samolus valerandi (Theophrastaceae) were studied using seeds collected during the years 2005-2007 from living plants in natural localities and from herbarium collections (Table 1). In natural localities, plants grew in habitats optimal for them. In each locality, seeds were collected from 15 individuals, and the representative seed sample was used for biometric measurements. Herbarium specimens were used to obtain seeds of two species; for Anagallis arvensis, a representative seed sample was composed of seeds from 20 individuals, and for Cyclamen purpurascens, seeds were obtained from the few individuals available. Measurements of seed and hilum size were carried out with light microscopy (LM) on 30 seeds of each species. Seed coat thickness was measured on five seeds of each species with the help of scanning electron microscopy (SEM) pictures. Seed length was measured along the longest axis in the plane of the hilum and microphyle, seed width along the longest axis at a $90^{\circ}$ angle to the plane of the hilum and microphyle, and seed thickness along the dorsiventral axis. Length and width of the hilum were also measured, and length/width ratio for both seed and hilum was calculated. For testa thickness, the inner (IL) and outer (OL) layers were measured on the longitudinal seed sections.

\section{Seed preparations for SEM}

Before cutting, seeds were fixed in a mixture of ethyl alcohol and acetic acid in a 3:1 proportion for $12 \mathrm{~h}$. After rinsing in distilled water (two times for $10 \mathrm{~min}$ ), they were sectioned at $-15^{\circ} \mathrm{C}$ in a cryostat LEICA CM 1850 , washed several times to remove the freezing medium, and dried using an acetone sequence in the following concentrations: $30,50,70,90$, and $100 \%$, three times for $6 \mathrm{~min}$ in each. 
Table 1 List of species analyzed in the study

\begin{tabular}{|c|c|c|c|}
\hline Family & Species & Specimen collection data & Figures \\
\hline Myrsinaceae & Anagallis minima $\mathrm{L}$. & $\begin{array}{l}\text { N } 53^{\circ} 35^{\prime} \\
\text { E } 18^{\circ} 35^{\prime} \\
\text { leg. Aneta Czarna }\end{array}$ & $4 \mathrm{f}-\mathrm{m}$ \\
\hline Myrsinaceae & Cyclamen purpurascens Mill. & $\begin{array}{l}\text { TRN Herbarium, PL } \\
\text { leg. Andrzej Zielski }\end{array}$ & $3 r-v$ \\
\hline Myrsinaceae & Glaux maritima $\mathrm{L}$. & $\begin{array}{l}\text { N } 52^{\circ} 10^{\prime} \\
\text { E } 17^{\circ} 41^{\prime} \\
\text { leg. Aneta Czarna }\end{array}$ & $3 m-q$ \\
\hline Myrsinaceae & Lysimachia nemorum $\mathrm{L}$. & $\begin{array}{l}\mathrm{N} 49^{\circ} 08^{\prime} \\
\mathrm{E} 22^{\circ} 34^{\prime} \\
\text { leg. Aneta Czarna }\end{array}$ & $4 n-r$ \\
\hline Myrsinaceae & Lysimachia vulgaris L. & $\begin{array}{l}\text { N } 52^{\circ} 21^{\prime} \\
\text { E } 15^{\circ} 52^{\prime} \\
\text { leg. Maria Morozowska }\end{array}$ & $3 a-d$ \\
\hline Myrsinaceae & Trientalis europaea L. & $\begin{array}{l}\text { N } 53^{\circ} 29^{\prime} \\
\text { E } 22^{\circ} 42^{\prime} \\
\text { leg. Aneta Czarna }\end{array}$ & $3 e-1$ \\
\hline Myrsinaceae & Anagallis arvensis $\mathrm{L}$. & $\begin{array}{l}\text { POZNB Herbarium, PL } \\
\text { leg. Aneta Czarna }\end{array}$ & $4 a-e$ \\
\hline Primulaceae & Androsace septentrionalis L. & $\begin{array}{l}\text { N } 53^{\circ} 46^{\prime} \\
\text { E } 20^{\circ} 28^{\prime} \\
\text { leg. Aneta Czarna }\end{array}$ & $5 \mathrm{a}-\mathrm{d}$ \\
\hline Primulaceae & Cortusa matthioli $\mathrm{L}$. & $\begin{array}{l}\text { N } 49^{\circ} 17^{\prime} \\
\text { E } 19^{\circ} 56^{\prime} \\
\text { leg. Aneta Czarna }\end{array}$ & $6 f-i$ \\
\hline Primulaceae & Hottonia palustris $\mathrm{L}$. & $\begin{array}{l}\text { N } 52^{\circ} 06^{\prime} \\
\text { E } 17^{\circ} 04^{\prime} \\
\text { leg. Aneta Czarna }\end{array}$ & $6 \mathrm{j}-\mathrm{n}$ \\
\hline Primulaceae & Primula elatior (L.) Hill & $\begin{array}{l}\mathrm{N} 49^{\circ} 08^{\prime} \\
\text { E } 22^{\circ} 34^{\prime} \\
\text { leg. Aneta Czarna }\end{array}$ & $5 e-1$ \\
\hline Primulaceae & Soldanella carpatica Vierh. & $\begin{array}{l}\text { N } 49^{\circ} 17^{\prime} \\
\text { E } 19^{\circ} 56^{\prime} \\
\text { leg. Aneta Czarna }\end{array}$ & $6 a-e$ \\
\hline Theophrastaceae & Samolus valerandi $\mathrm{L}$. & $\begin{array}{l}\text { N } 52^{\circ} 10^{\prime} \\
\text { E } 17^{\circ} 41^{\prime} \\
\text { leg. Aneta Czarna }\end{array}$ & $60-r$ \\
\hline
\end{tabular}

For SEM, seeds and seed cuttings were covered with gold and examined with a Zeiss EVO 40 electron microscope at $8-15 \mathrm{kV}$ depending on the species.

\section{Statistical analysis}

The biometric data were analyzed statistically. For each seed trait, one-factor analysis of variance (ANOVA) was used to examine differences in means among species studied. If critical differences were noted, multiple comparisons were carried out based on Tukey's test for equal sample sizes. To show similarities and differences among taxa studied, Ward's hierarchical clustering method was used to compute cluster groups of species based on the seed characters analyzed. Statistical analyses were performed using JMP 8.0 (SAS Institute, Cary, NC, USA; http://www.sas.com/).

The specimens and the seed material are deposited in the herbarium of the Botany Department (POZNB), Poznan University of Life Sciences, Poland. 


\section{Results}

Seed shape and size

To describe seed shape for the species examined, we have adopted two of the three major shape types proposed by $\mathrm{Oh}$ et al. (2008). These were the sectoroid seed shape, which was observed for seeds of Androsace septentrionalis, Cortusa matthioli, Soldanella carpatica (Primulaceae), Anagallis arvensis, A. minima, G. maritima, Lysimachia nemorum, L. vulgaris, and T. europaea (Myrsinaceae), and the polyhedral seed shape, which was observed for seeds of $P$. elatior (Primulaceae) and Samolus valerandi (Theophrastaceae) (Table 2). We have described two other seed shape types: suboval and subglobose with a concave hilar area (Fig. 1). The suboval shape corresponds to the lateral view of the seed and is typical for $H$. palustris. Seeds are laterally flattened, and the lateral faces are slanted towards the ventral margin. The hilum is located along the ridge on the top side (Fig. 6j, k). Subglobose seeds are typical for Cyclamen purpurascens. Their shape is similar to rugose seeds described by $\mathrm{Oh}$ et al. (2008) for Asterolinon linum-stellatum, but their surface is not rugose. In dorsal view they are elliptic, and on the ventral side, they have a concave hilar area (Fig. 3r, s). Three seed size categories were distinguished: small, medium, and large. Most of the species examined have small seeds with the following length, width, and thickness ratios: $0.5-1.6 \times 0.3-1.2 \times 0.4-0.8 \mathrm{~mm}$. T. europaea has medium size seeds $(1.6 \times 1.4 \times 0.6 \mathrm{~mm})$, and seeds of Cyclamen purpurascens are substantially larger than all other species $(2.8 \times 2.4 \times 1.3 \mathrm{~mm})$ (Table 2$)$.

Statistical analyses showed significant differences $(P<0.0001)$ among species studied for all features analyzed (Tables 3, 4). Ward's agglomerative grouping method distinguished three main groups of taxa (Fig. 2). Two of them comprise species representing both Primulaceae and Myrsinaceae, and Cyclamen purpurascens is isolated in the third one. In the first group, the closest similarities were found for species representing the same family, while in the second group, the closest similarities were observed for species representing different families and different shape types. Multiple comparisons based on Tukey's test showed the presence of two uniform groups of species based on mean values of the length/width ratio. The first group included all species of Myrsinaceae examined and only one species of Primulceae, i.e., P. elatior, while the second group included all other species of Primulaceae (except Soldanella carpatica) and Samolus valerandi of Theophrastaceae (Table 3). Despite the different sizes and shape types of seeds, length/width proportions remained fairly similar within particular families $(\mathrm{CV}=23.4 \%)$. In contrast, the hilum length/width ratio was found to be a highly variable feature $(\mathrm{CV}=53.7 \%)$ (Table 4).
The species examined were characterized by either narrow, narrowly elliptic, or elliptic hilum shapes (ratios from longest axis to shortest axis ranged from $8: 1$ to $5: 1,4.5: 1$ to 2.5:1, and 2:1 to $1.5: 1$, respectively).

Most of the examined species of Primulaceae and Myrsinaceae have narrowly elliptic or elliptic hila more or less flush with the surface. Soldanella carpatica, Cortusa matthioli, and Samolus valerandi have narrow hilum (Fig. 6a, b, f, o), and Cyclamen purpurascens has extremely different, elliptic immersed concave hila (Fig. 3s; Table 2). Seeds of Cyclamen purpurascens were also significantly different from seeds of Myrsinaceae, Primulaceae, and Theophrastaceae in all other biometric features (Tables 3, 4). In turn, seeds of Samolus valerandi were found to be very similar to seeds of Anagallis minima according to testa thickness, and no significant differences were noted between these species for seed length, width, or thickness.

\section{Seed surface and testa thickness}

Three types of the seed sculpture were observed among all species examined. The most common was reticulate ornamentation of the seed surface, observed for $G$. maritima (Fig. 3n), Cyclamen purpurascens (Fig. 3t), Androsace septentrionalis (Fig. 5b), Soldanella carpatica (Fig. 6c), Cortusa matthioli (Fig. 6h), H. palustris (Fig. 6l), and Samolus valerandi (Fig. 6q). The reticulate and partly vesiculose seed pattern of Cortusa matthioli and the reticulate seed sculpture of Soldanella carpatica were also characterized by secondary sculpture; in Cortusa matthioli the surface of the outer cell walls exhibited a striate microornamentation (Fig. 6h) and in Soldanella carpatica small secondary protrusions were observed (Fig. 6d). A tuberculate seed surface pattern characterized $P$. elatior seeds, and tuberculate sculpture with secondary striations was observed for Anagallis arvensis, A. minima, and Lysimachia nemorum (Fig. 4d, i, p). Two species, Lysimachia vulgaris and $T$. europaea, were characterized by the presence of a sponge-like outer layer with a poroid-alveolate surface pattern. On L. vulgaris seeds, this outer layer has a columnar look (Fig. 3b) that was previously described by Oh et al. (2008). The observed thickness of the outer layer was about $80-110 \mu \mathrm{m}$ (Table 2). The sponge-like outer layer on $T$. europaea seeds consists of rectangular cells (RC) with a roof-like upper wall and longitudinal thickenings on the inner cell wall surface (Fig. 3j). The thickness of the outer layer for this species was about 30-62 $\mu \mathrm{m}$ (Table 2). The surface of the sponge-like outer layer on $T$. europaea sometimes showed a reticulate pattern with secondary striations (Fig. 3g). Testa structure of all species examined was characterized by two layers, an inner layer (IL) and outer layer (OL) of different thicknesses, which 


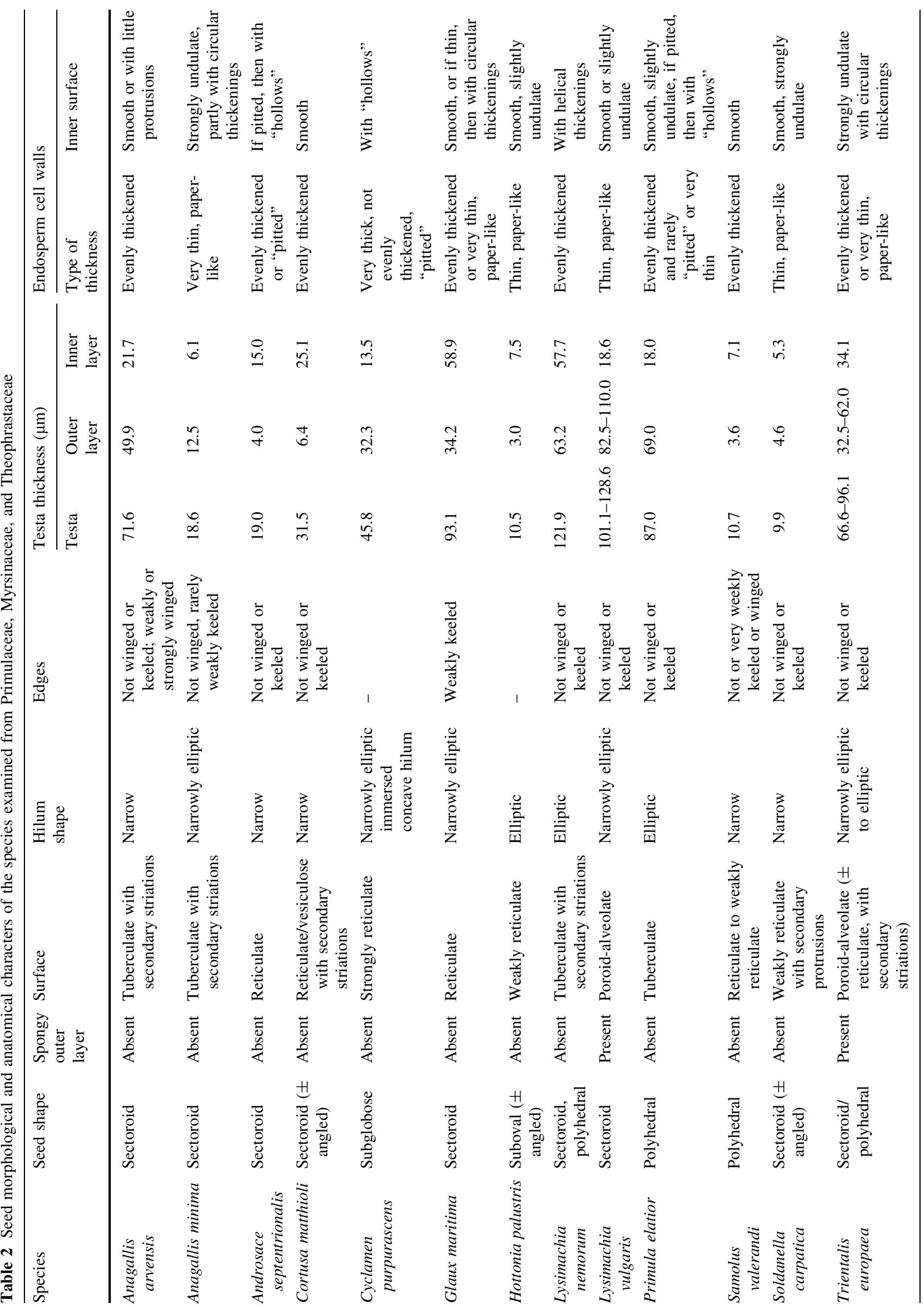



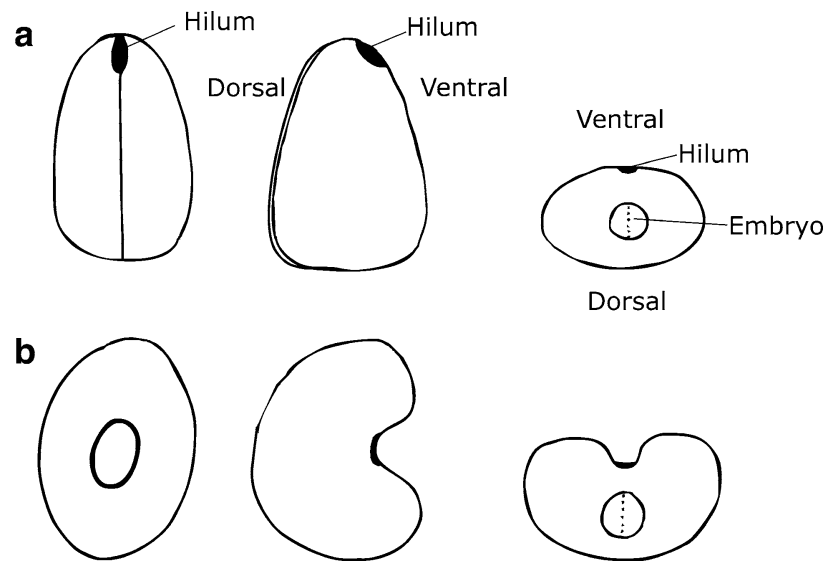

Dorsal

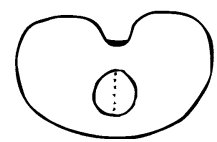

Fig. 1 Schematic illustration of seed shapes of a Hottonia palustris (suboval laterally flattened, side faces, cavernous, and slanted towards the ventral margin) and b Cyclamen purpurascens (subglobose with concave hilar area). Seed shape in ventral view (left column), lateral view (middle column), and transverse section (right column)

closely adhere to each other. Primulaceae seeds had a smaller range of testa thickness $(9.9-87.0 \mu \mathrm{m})$ than seeds of Myrsinaceae (18.6-128.6 $\mu \mathrm{m})$. Seeds with especially thin testa were found for Soldanella carpatica, H. palustris, and Samolus valerandi for which testa thickness ranged from 9.9-10.7 $\mu \mathrm{m}$ (Table 2). For all species examined with reticulate seed coat patterns, the inner testa layer was thicker than the outer testa layer (ratios of inner layer to outer layer ranged from 1.7:1 to 3.9:1). The opposite pattern was found for seeds with tuberculate seed sculpture and seeds with presence of the sponge-like outer layer. For example, in seeds with rather thick testa $(71.6-96.1 \mu \mathrm{m})$, such as P. elatior (Fig. 5h, i, j) (Primulaceae), Anagallis arvensis (Fig. 4e), and T. europaea (Fig. 3j) (Myrsinaceae), the ratio of the thickness of the inner/outer testa layers was 1:3.8, 1:2.3, and 1:1.8, respectively. In seeds of Lysimachia nemorum (Fig. 4q) and L. vulgaris (Fig. 3a, b), in which the testa was very thick $(121.9-128.6 \mu \mathrm{m})$, the same ratios were 1.1:1 and 5.9:1, respectively (Table 2). The feature common for all species examined was the presence of oxalate crystals on the surface of the inner testa layer (Figs. 3j, o, u; 4e, m; 5h, 1; 6m). For Androsace septentrionalis (Fig. 5b), Soldanella carpatica, and Cortusa matthioli (Fig. 6c, h), outlines of crystals were visible on the ventral view of the seed surface, under the cuticle cell layer.

\section{Endosperm structure}

Endosperm structure differed strongly among species examined. We have defined two endosperm characters: cell wall thickness and the relief of the inside cell wall surfaces. Four main types of endosperm were distinguished: (1) with evenly thickened cell walls and smooth inside cell wall surfaces, (2) with evenly thickened cell walls and circular or helical thickenings on their inside surfaces, (3) with very thick, unevenly thickened cell walls with constrictions ("pitted") and with dark deep hollows on the inside cell wall surfaces, (4) with very thin, paper-like cell walls slightly or strongly undulate. The first type of endosperm was found in seeds of Anagallis arvensis, for which little protrusions were also observed on the inner cell wall surfaces (Fig. 4e). The same type of endosperm, but without protrusions, was typical for G. maritima, Cortusa matthioli, and Samolus valerandi seeds (Figs. 3p; 6i, r). The endosperm structure of T. europaea and G. maritima seeds was very variable, as two different types of endosperm structure were present in them (Fig. 3k, 1, p, q). The second endosperm type was found in Lysimachia nemorum seeds (Fig. 4r). The third type was found in seeds of Cyclamen purpurascens, Androsace septentrionalis, and P. elatior (Figs. 3v; $5 \mathrm{~d}, \mathrm{i}, \mathrm{j}, \mathrm{k}$ ). It is worth mentioning that in seeds of $P$. elatior, the endosperm structure was not uniform, as its cells located on the end of the longest axis were characterized by papery thin cell walls (Fig. 5j). The fourth endosperm type was observed in seeds of G. maritima (Fig. 3q), Anagallis minima (Fig. 4k, 1), and Soldanella carpatica (Fig. 6e), consisting of cells with very strongly undulate walls. The same type of endosperm was found in seeds of Lysimachia vulgaris, T. europaea (Fig. 3d, k), and H. palustris (Fig. 6m, n), in which the cell walls were only slightly undulate.

\section{Discussion}

Recent molecular and morphological phylogenetic studies on the relationships among taxa of "primuloid" families of the Ericales s.l. (Primulaceae, Myrsinaceae, and Theophrastaceae) have shown that, despite molecular evidence for close relationships of certain taxa, the addition of morphological information may lead to a slight increase, or decrease, in support for phylogenetic relationships of some groups (Anderberg et al. 2007; Oh et al. 2008). Based on our observations, the testa thickness, presence or absence of oxalate crystals in the outer testa layer, and the endosperm structure are very important features that may be potentially informative characters of systematic importance. According to the general rule (Anderberg and Ståhl 1995), the subglobose seeds of the former MyrsinaceaeMyrsinoideae have "pitted" endosperm cell walls and their testa are devoid of crystals, while the angular seeds of the former Primulaceae have evenly thickened, smooth endosperm cell walls and rather thick, usually distinctly twolayered testa, generally with rhomboid crystals. However, among species we examined for this study, we found angular seeds of the former Primulaceae with either thin or 


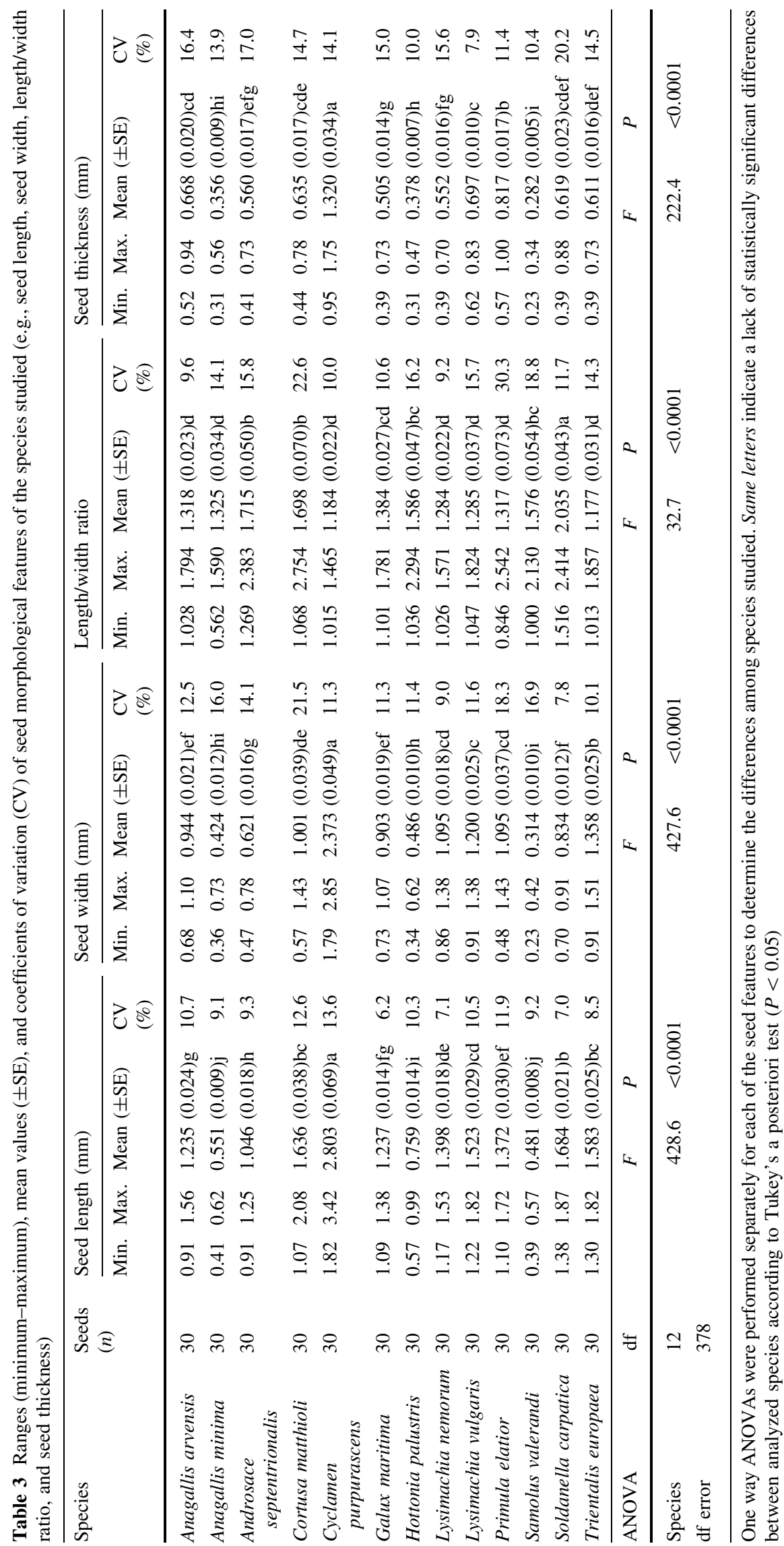




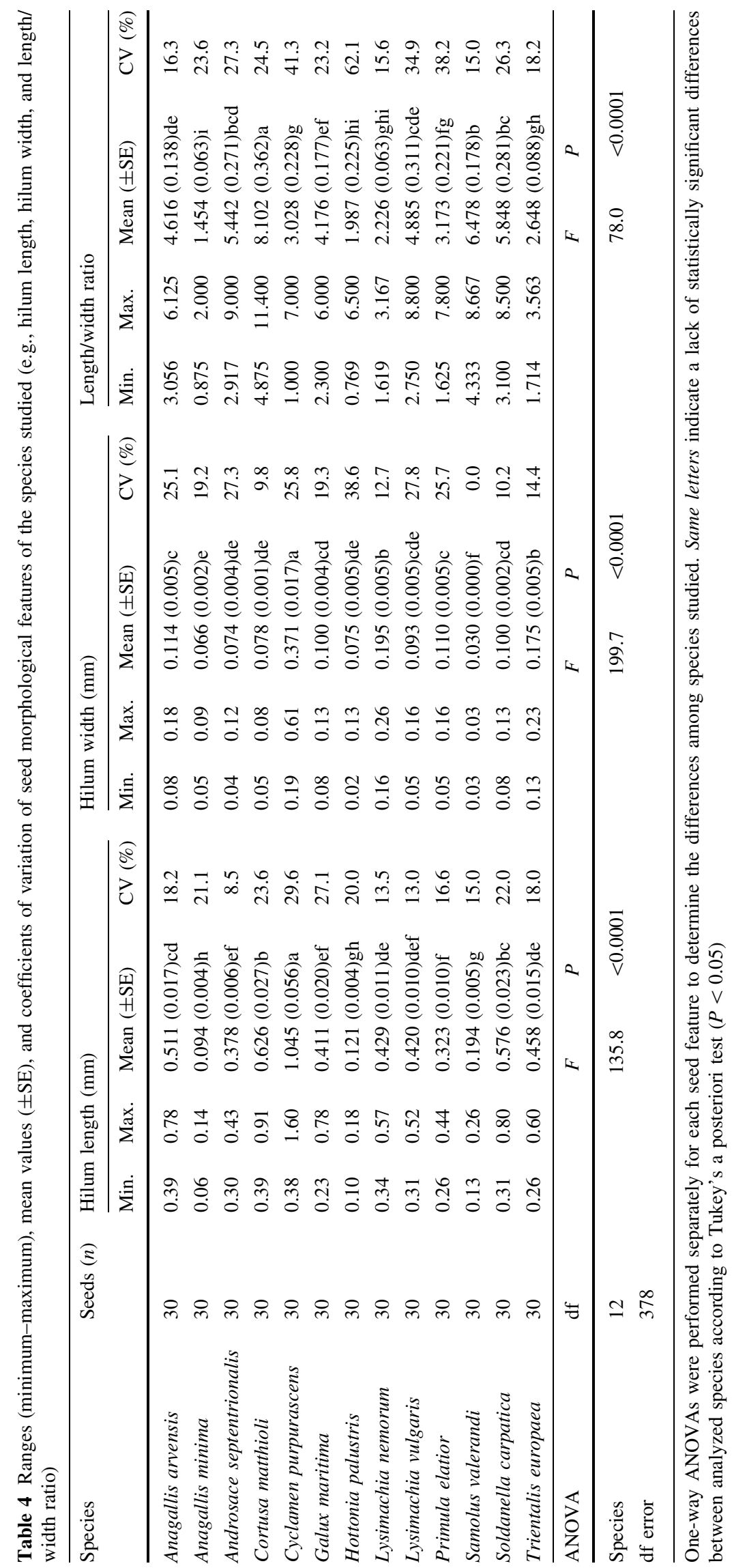


- Anagallis arvensis

- Lysimachia vulgaris

- Glaux maritima

- Primula elatior

- Lysimachia nemorum

- Trientalis europaea

- Cortusa matthioli

- Soldanella carpatica

- Androsace septentrionalis

- Samolus valerandi

- Anagallis minima

- Hottonia palustris

- Cyclamen purpurascens
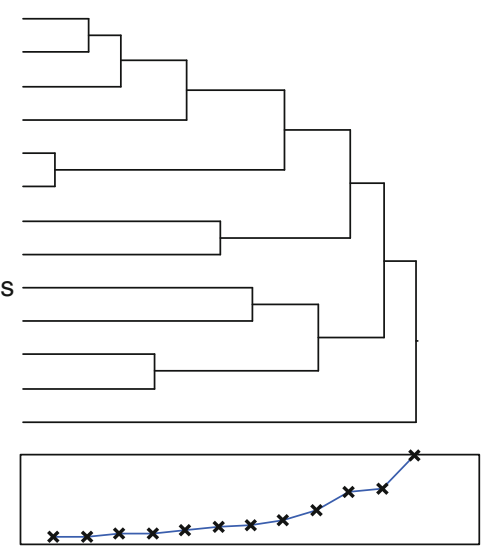

Fig. 2 Dendrogram of cluster groupings of the species studied on the basis of seed morphological features

thick testa. After the reclassification of that family and transferring such species as Lysimachia, Anagallis, Trientalis, Glaux, and Cyclamen to Myrsinaceae (Källersjö et al. 2000), only P. elatior (among those species examined) was characterized by thick testa. This is in agreement with the results of our previous study in which the presence of rather thick testa was also described for $P$. veris seeds (Klimko et al. 2001). In this study we observed endosperm with irregularly thickened cell walls with constrictions in seeds of not only Cyclamen purpurascens (which fits well with the description of Myrsinaceae), but also in small angular seeds of P. elatior and Androsace septentrionalis. Anderberg and Kelso (1996) in their earlier investigations on phylogenetic implications of endosperm cell wall morphology in Douglasia, Androsace, and Vitaliana (Primulaceae), noted that the endosperm of Primula and Androsace is characterized by evenly thickened cell walls without constrictions. According to the same authors, the endosperm cell walls with irregular thickening and narrow constrictions characterizes all Douglasia and Vitaliana species and supports the monophyly of these genera. However, a few years later Ståhl and Anderberg (2004) found that in seeds of some Androsace, the endosperm consists of cells with unevenly thickened cell walls with narrow constrictions. We have found Androsace septentrionalis to be another example of an Androsace species with "pitted" endosperm cell walls. According to our observations, the feature of the irregularly thickened endosperm cell walls is due to the presence of the deep dark hollows on the inner surface of the cell walls, and such hollows were observed by us in seeds of $P$. elatior and Androsace septentrionalis.

The presence of endosperm with very thin, paper-like cell walls and slight or strong undulations, which was observed in seeds of Anagallis minima, G. maritima, and $T$. europaea, the three species transferred recently to Myrsinaceae (Källersjö et al. 2000), as well as in seeds of
Lysimachia vulgaris, may suggest that this type of endosperm structure is common among Myrsinaceae species. However, in seeds of Lysimachia nemorum, although the endosperm cell walls were rather thin and undulate, the relief of their inside wall surfaces was rather different, characterized by the presence of very distinct helical thickenings.

Results of this study show that rhomboid crystals can be present in testae of subglobose and angular seeds, so that this feature is not exclusive to small angular seeds, and lack of crystal presence in subglobose seeds of Cyclamen purpurascens before now does not support the transfer of that species to Myrsinaceae. Our results concerning seed structure of other species of the present Myrsinaceae, such as Anagallis arvensis and A. minima, for which there are many different reports concerning their molecular and morphological similarity (Martins et al. 2003; Manns and Anderberg 2005), showed on one hand very close similarity of their tuberculate seed sculpturing with secondary striations, while on the other hand, the results on other features examined did not confirm that similarity. For example, seeds of these two species differed in the presence or absence of winged and keeled seed edges, respectively. The testa was more than three times thicker in seeds of Anagallis arvensis than in seeds of A. minima, and striking differences in endosperm structure of these two species were observed. In Anagallis arvensis, seed endosperm consisted of cells with evenly thickened smooth cell walls, while in seeds of A. minima, the endosperm cell walls were papery, thin, and strongly undulate. Differences in the seed structure observed in these two species are in agreement with the results of molecular studies showing their distant phylogenetic relationships (Martins et al. 2003).

Our results concerning description and comparison of the seed structure of Anagallis arvensis and Lysimachia nemorum, for which there is strong molecular evidence of a very close relationship (Källersjö et al. 2000; Manns and Anderberg 2007; Oh et al. 2008), add some more morphological support for the reclassification of Anagallis from Primulaceae to Myrsinaceae. Similarities in the seed shape, seed sculpture, presence of oxalate crystals as well as thickness of endosperm cell walls within these two species were observed. However, we found one obvious difference between them: the relief of the inside surface of endosperm cell walls, which in L. nemorum is characterized by helical thickenings. One other difference concerns the testa thickness, which was more than 1.5 times thicker in seeds of $L$. nemorum than in seeds of A. arvensis. To resolve the differentiation between these two species, more taxa from both genera should be examined.

Some of our results showed similarities in the seed structure of $H$. palustris and Soldanella carpatica. These 
Fig. 3 Seeds of a-

d Lysimachia vulgaris,

e-l Trientalis europaea,

m-q Glaux maritima, and

$\mathbf{r}-\mathbf{v}$ Cyclamen purpurascens. $\mathbf{m}$,

s Ventral view showing

narrowly elliptic (m) hilum

$(H)$ and concave hilar area (s).

e, $\mathbf{r}$ Dorsal view showing seed

outline and the reticulate surface pattern. c, $\mathbf{g}, \mathbf{h}$, i Surface of the spongy outer layer of

Lysimachia vulgaris (c) and

Trientalis europaea seeds (g, $\mathbf{h}$,

i). n, t Reticulate (n) and strongly reticulate (t) pattern of the outer layer $(O L)$. f Partly removed spongy outer layer showing presence of oxalate crystals $(O x C ;$ arrow $) . \mathbf{a}, \mathbf{b}, \mathbf{j}, \mathbf{o}$, u Longitudinal sections (L.S.) showing testa $(T)$ thickness and rhomboid crystals (arrows) on the surface of the inner layer (IL). b, j L.S. showing columnar cells $(C C)$ and rectangular cells $(R C)$ of spongy outer layers of Lysimachia vulgaris (b) and Trientalis europaea (j) seeds. d, k L.S. showing very thin, papery walls of endosperm (End). 1 L.S. showing endosperm cells with evenly thickened, undulate walls with circular thickenings on the inner cell walls surface. $\mathbf{p}, \mathbf{q}$ L.S. showing Glaux maritima endosperm cells with smooth evenly thickened (p) and papery thin, with circular thickenings on the inner cell wall surface (q). v L.S. showing "pitted" endosperm structure with unevenly thickened endosperm cell walls with dark hollows on the inside cell wall surfaces (arrows)
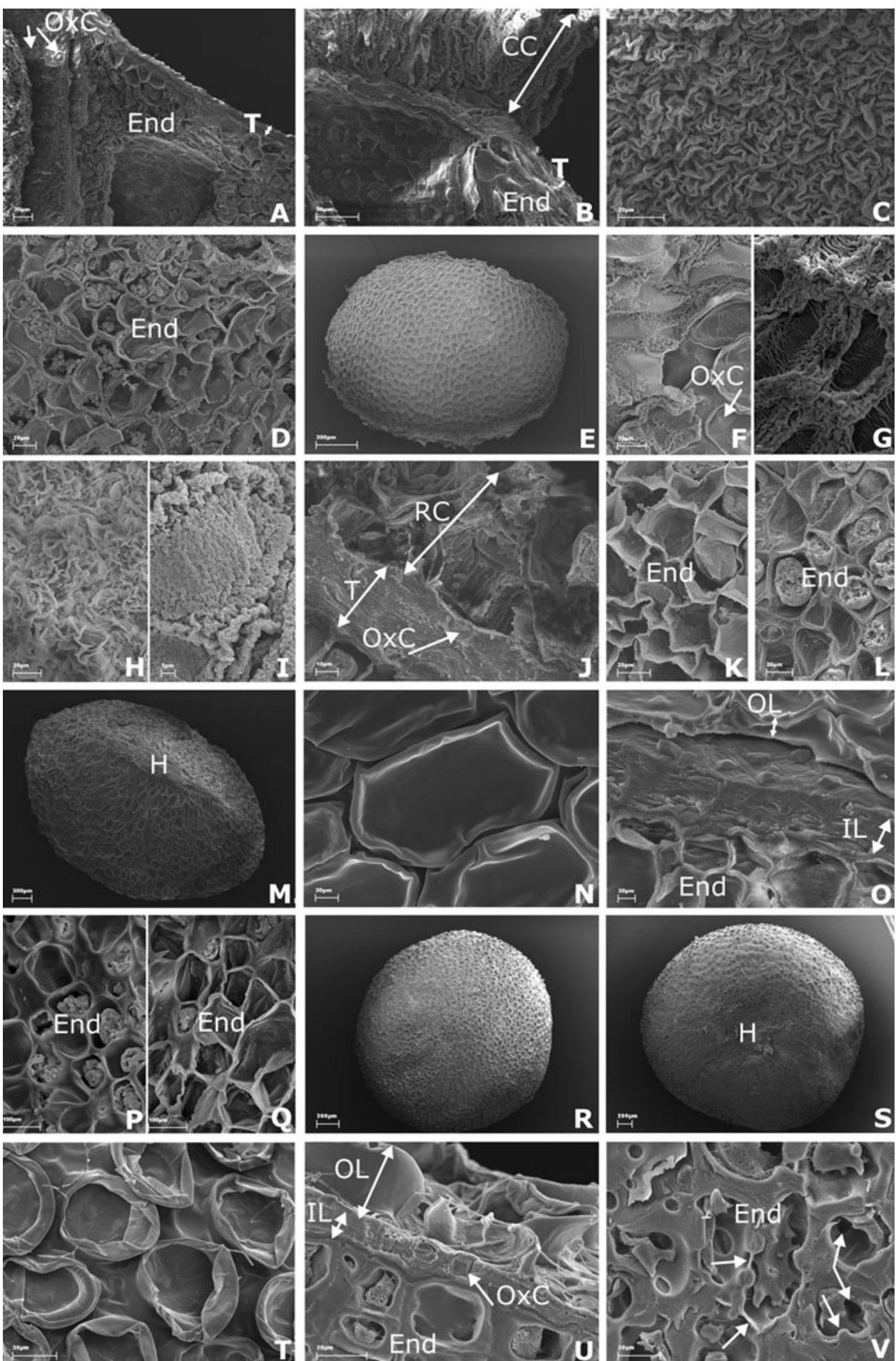

included the reticulate seed pattern, very thin testae, presence of rhomboid crystals, and very thin, papery, and smooth endosperm cell walls. According to some earlier molecular studies (Trift et al. 2002; Martins et al. 2003), there is some support for the assumption of common ancestry of Hottonia and Soldanella. Similarities in the seed structure of these two species we describe here adds support for that hypothesis.

The inclusion of Samolus valerandi in the family Theophrastaceae is the subject of much discussion, as there is very weak morphological support for its transfer to that family (Källersjö and Ståhl 2003; Martins et al. 2003; Caris 
Fig. 4 Seeds of a-e Anagallis arvensis, $\mathbf{f}-\mathbf{m}$ A. minima, and $\mathbf{n}-\mathbf{r}$ Lysimachia nemorum. a, $\mathbf{f}$, o Ventral view showing narrowly elliptic (a, f) and elliptic (o) hilum $(H)$ shape. b, g, n Dorsal view showing lack of winged or keeled edges of dorsal faces. c, h Lateral view showing strongly winged edges of dorsal face (c) and lack of winged or keeled dorsal face (h). d, i, p Seed surface showing tuberculate pattern with secondary striations. j Seed surface with partly removed outer layer $(O L)$ and crystal visible on the surface of the inner layer $(I L)$. e, $\mathbf{m}$,

q Longitudinal section (L.S.) showing testa thickness and presence of oxalate crystals (OxC; arrows) on the surface of the inner layer $(I L)$. e, $\mathbf{k}, \mathbf{l}$, r L.S. showing endosperm (End) structure with evenly thickened cell walls with little protrusions on the inner cell wall surfaces (e); very thin, papery cell walls $(\mathbf{k}, \mathbf{l})$; evenly thickened cell walls with helical thickening on the inner cell wall surfaces $(\mathbf{r})$
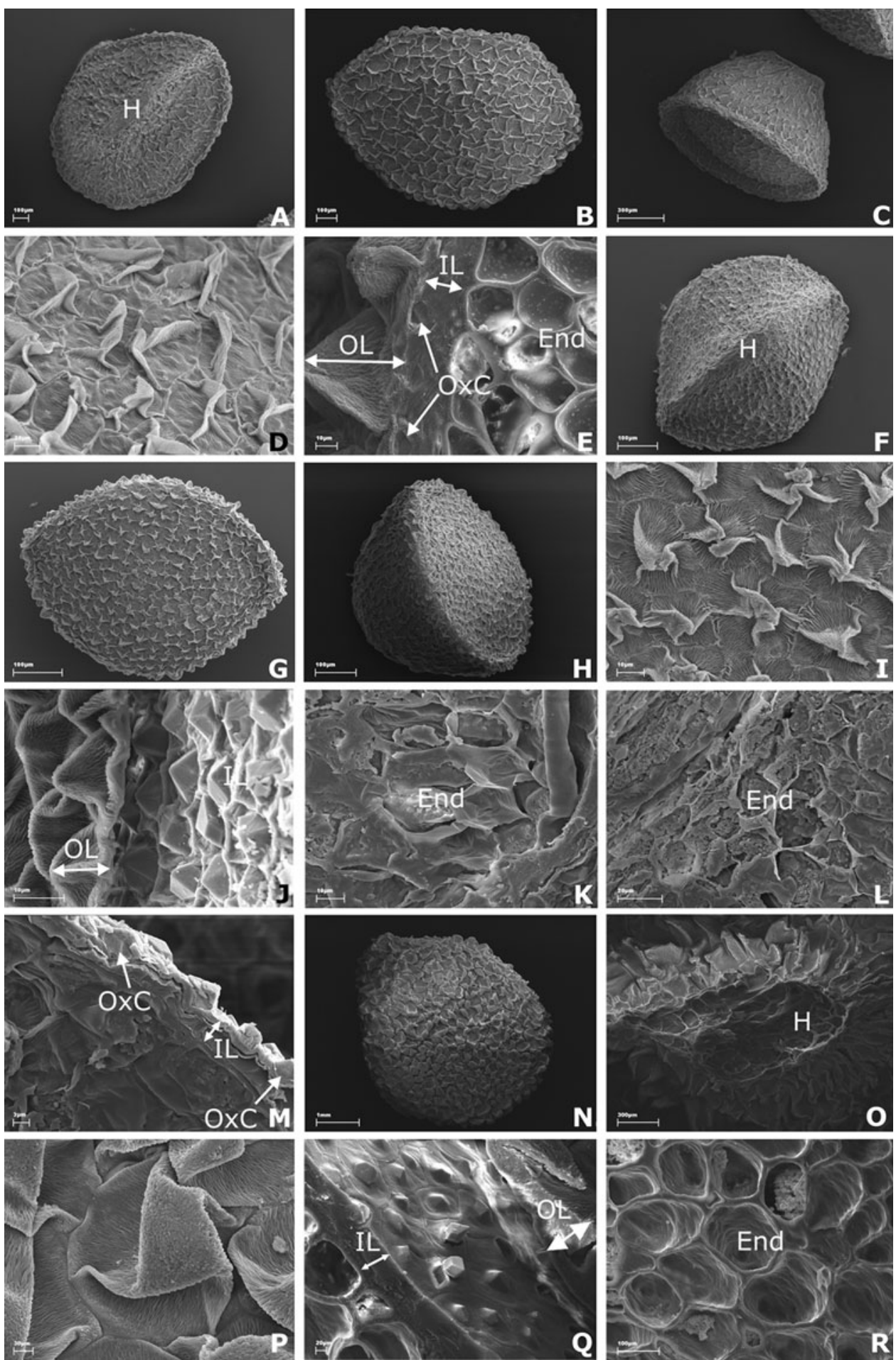

and Smets 2004). We found that seeds of Samolus valerandi were very similar to seeds of $H$. palustris and Soldanella carpatica (Primulaceae) in size proportions, faintly reticulate seed ornamentation, presence of oxalate crystals, and very thin testae. Some similarity (due to the presence of very thin testae) was observed between seeds of $S$. valerandi and seeds of Androsace septentrionalis
(Primulaceae) and Anagallis minima (Myrsinaceae). The structure of very thin testa in seeds of $S$. valerandi was described in our earlier study (Morozowska and Czarna 2006). On the other hand, thickness of the endosperm cell walls in seeds of $S$. valerandi differed from the endosperm structure in seeds of the species mentioned above; seeds of A. septentrionalis had endosperm with "pitted" cell walls 
Fig. 5 Seeds of a-d Androsace septentrionalis and e-1 Primula elatior. a, f Ventral view showing linear (a) and elliptic (f) hilum $(H)$ shape. e Dorsal view showing lack of winged or keeled edges of dorsal face. b Outer layer $(O L)$ surface with reticulate seed pattern and oxalate crystals $(\mathrm{OxC})$ visible under cuticle cells (arrows). g Tuberculate seed pattern. $\mathbf{c}, \mathbf{h}$, I Longitudinal section (L.S.) showing testa $(T)$ thickness and presence of oxalate crystals (h, l; arrows) on the surface of the inner layer $(I L)$. c, d, i, j, k L.S. showing endosperm (End) structure with irregular thickenings of the cell walls and dark hollows on the inner cell wall surfaces (arrows)
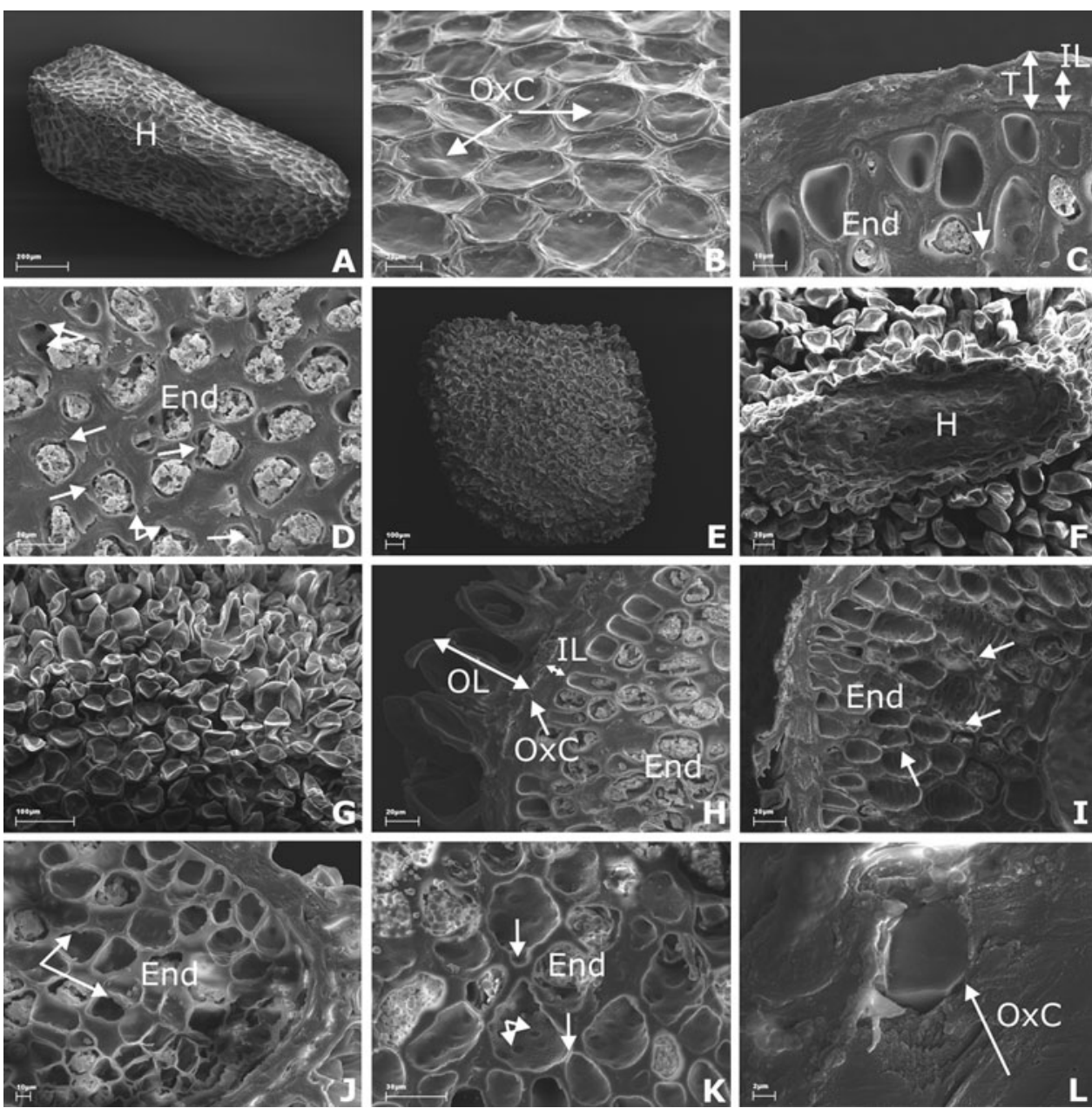

while the other species were characterized by papery thin endosperm cell walls. In general, the features of $S$. valerandi seeds we described compare well with the description of Theophrastaceae seeds given by Ståhl and Anderberg (2004), according to whom seeds of Theophrastaceae are characterized by faintly reticulate seed ornamentation and endosperm with smooth or irregularly thickened cell walls. In our opinion, the best way to find more, stronger morphological support for transferring Samolus to Theophrastaceae would be to examine the seed structure of the large number of species of that genus.

With regard to Cyclamen purpurascens, whose placement within Myrsinaceae is still under discussion (Martins et al. 2003), we found that, although the genus Cyclamen is characterized by capsular fruits, its seed shape and hilum, rather thin testae and "pitted" endosperm cell walls bear a good resemblance to the description of seeds typical for drupaceous species from Myrsinaceae (Ståhl and Anderberg 2004). The only feature that contradicts that description was the presence of oxalate crystals observed on the surface of the inner testa layer.
In conclusion, our study of the seed structure of some species of Primulaceae, Myrsinaceae, and Theophrastaceae provided some important new data concerning seed shape and size, seed coat pattern, presence of oxalate crystals on the surface of the outer testa layer, thickness of testa, and endosperm structure. In general, seeds, as generative organs that are only slightly influenced by environmental conditions, are important diagnostic features (but see Janyszek et al. 2008; Janyszek and Jagodzinski 2009). Their high structural diversity provides the most valuable criteria for classification at species and family levels. Thus, a detailed analysis of the morphological and anatomical structure of seeds greatly increases our knowledge of individual species and may be helpful in better understanding the phylogeny of the taxa examined. According to our observations, the relief of the secondary wall thickenings forming the secondary seed sculpture on some of the seeds examined is of high systematic importance. In any case, for purposes of comparative systematics, it is necessary to define these secondary sculptures structurally. Their nature can often be revealed by TEM examinations of thin 
Fig. 6 Seeds of a-e Soldanella carpatica, $\mathbf{f}-\mathbf{i}$ Cortusa matthioli, j-n Hottonia palustris, and o-r Samolus valerandi. $\mathbf{a}, \mathbf{f}, \mathbf{j}$, o Ventral view showing narrow $(\mathbf{a}, \mathbf{f})$ and narrowly elliptic (j,

o) hilum $(H)$ shape. j, k Ventral (j) and lateral (k) view showing suboval seed shape with cavernous lateral faces. p Dorsal view showing very weakly keeled edges between dorsal and lateral faces. c, $\mathbf{d}$ Outer surface layer with reticulate seed pattern with secondary protrusions. g, h Reticulate/ vesiculose seed pattern with secondary striations and oxalate crystals $(O x C)$ visible under cuticle cells (h) (arrows). l, q Weakly reticulate seed pattern with oxalate crystals visible under cuticle cells. c, i, m, r Longitudinal sections showing testa $(T)$ thickness and presence of oxalate crystals (arrows) on the surface of the inner layer. $\mathbf{e}, \mathbf{i}, \mathbf{m}, \mathbf{n}, \mathbf{r}$ Longitudinal sections showing endosperm (End) structure with evenly thickened cell walls (i, r) and very thin, papery cell walls slightly $(\mathbf{m}, \mathbf{n})$ or very strongly (e) undulate
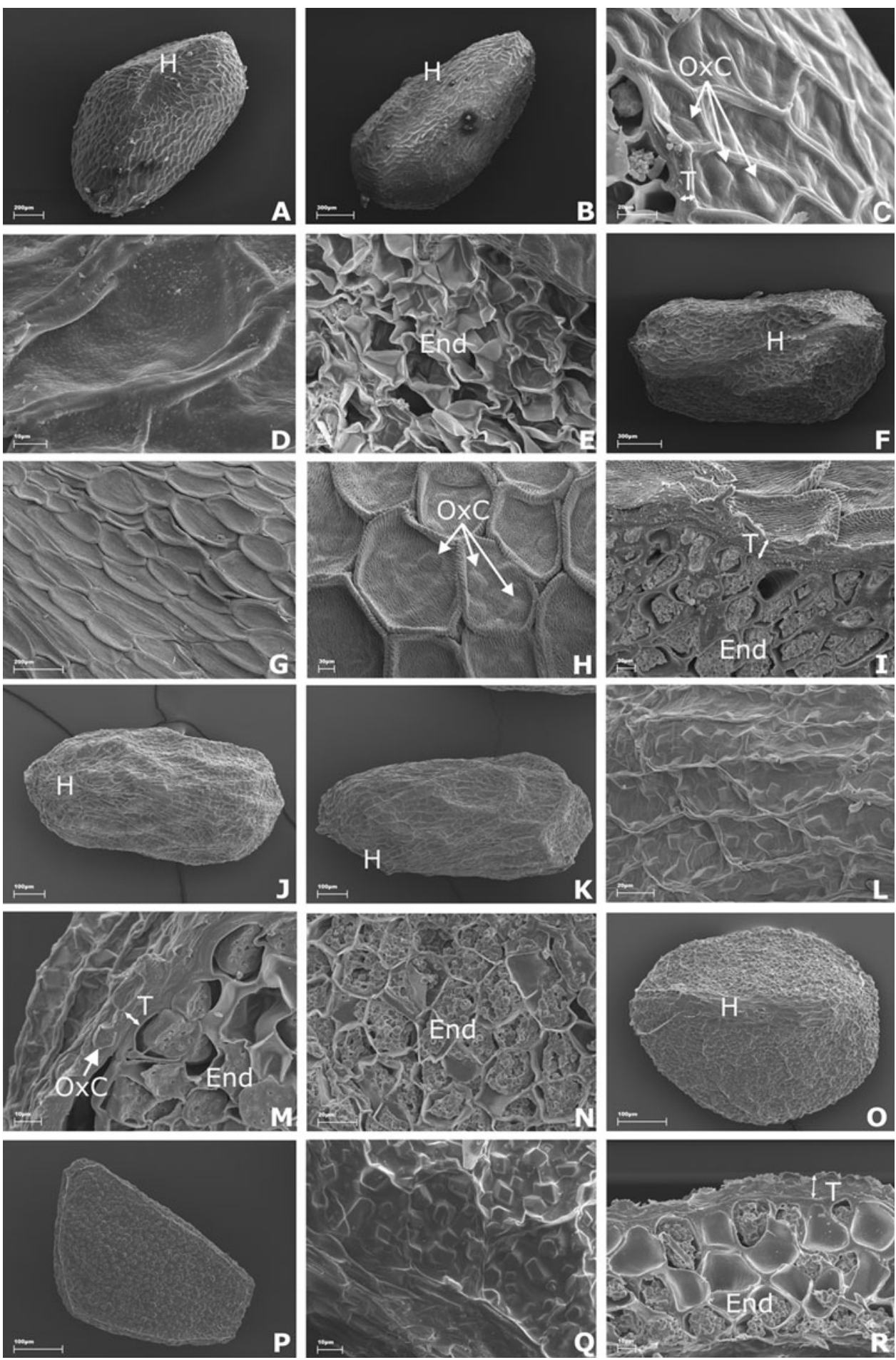

sections (Barthlott 1990). We also conclude that the presence of oxalate crystals in testae, which were observed in seeds of all species examined, should not be used as the feature distinguishing species with angular or subglobose seeds. The other character that in our opinion is of high systematic interest is the endosperm structure, especially the thickenings of the cell walls and their inner surface relief. In analyzing those features, we have shown some similarities in endosperm structure between species from different genera and families not reported earlier. However, as a single source of characters, endosperm structure cannot be expected to resolve all unclear relationships among 
the families examined. Such studies should be continued, based on a broader sampling of taxa, and including both molecular and morphological evidence.

Acknowledgments We kindly thank Dr. Lee E. Frelich (University of Minnesota, USA) for linguistic support and valuable comments on the early draft of the manuscript. The authors would like to thank two anonymous reviewers for their suggestions and comments made on an earlier version of the manuscript.

Open Access This article is distributed under the terms of the Creative Commons Attribution Noncommercial License which permits any noncommercial use, distribution, and reproduction in any medium, provided the original author(s) and source are credited.

\section{References}

Anderberg AA, Kelso S (1996) Phylogenetic implications of endosperm cell wall morphology in Douglasia, Androsace, and Vitaliana (Primulaceae). Nordic J Bot 16:481-486

Anderberg AA, Ståhl B (1995) Phylogenetic interrelationships in the order Primulales, with special emphasis on the family circumscriptions. Can J Bot 73:1699-1730

Anderberg AA, Ståhl B, Källersjö M (1998) Phylogenetic relationships in the Primulales inferred from $r b c \mathrm{~L}$ sequence data. Pl Syst Evol 211:93-102

Anderberg AA, Ståhl B, Källersjö M (2000) Maesaceae, a new primuloid family in the order Ericales s.1. Taxon 49:183-187

Anderberg AA, Rydin C, Källersjö M (2002) Phylogenetic relationships in the order Ericales s.l.: analyses of molecular data from five genes from the plastid and mitochondrial genomes. Am J Bot 89:677-687

Anderberg AA, Manns U, Källersjö M (2007) Phylogeny and floral evolution of the Lysimachieae (Ericales, Myrsinaceae). Evidence from ndhF sequence data. Willdenowia 37:407-421

Barthlott W (1990) Scanning electron microscopy of the epidermal surface in plants. In: Claugher D (ed) Scanning electron microscopy in taxonomy and functional morphology. Clarendon, Oxford, pp 69-94

Caris P, Smets E (2004) A floral ontogenetic study on the sister group relationship between the genus Samolus (Primulaceae) and the Theophrastaceae. Am J Bot 91:627-643

Caris P, Decraene LPR, Smets E, Clinckemaillie D (2000) Floral development of three Maesa species, with special emphasis on the position of the genus within Primulales. Ann Bot 86:87-97

Hao G, Hu C-M (2001) Phylogenetic relationships in Lysimachia (Primulaceae): a cladistic analysis. J Trop Subtrop Bot 9:93-100
Hao G, Yuan Y-M, Hu C-M, Ge X-J, Zhao N-X (2004) Molecular phylogeny of Lysimachia (Myrsinaceae) based on chloroplast trnL-F and nuclear ribosomal ITS sequences. Molec Phylogenet Evol 31:323-339

Janyszek M, Jagodzinski AM (2009) Variability of perigynium morphology of Central European members of Carex sect. Phaestoglochin (Cyperaceae) from variable plant communities. Pl Syst Evol 278:87-99

Janyszek M, Jagodzinski AM, Janyszek S, Wronska-Pilarek D (2008) Morphological variability of Carex spicata Huds. utricles among plant communities. Flora 203:386-395

Källersjö M, Ståhl B (2003) Phylogeny of Theophrastaceae (Ericales s.lat.). Int J Plant Sci 164:579-591

Källersjö M, Bergqvist G, Anderberg AA (2000) Generic realignment in primuloid families of the Ericales s.l.: a phylogenetic analysis based on DNA sequences from three chloroplast genes and morphology. Am J Bot 87:1325-1341

Klimko M, Morozowska M, Piskorz R (2001) Mikromorfologiczne zróżnicowanie nasion Primula veris L. ssp. veris (Primulaceae). Rocz AR Pozn Bot 4:103-117

Manns U, Anderberg AA (2005) Molecular phylogeny of Anagallis (Myrsinaceae) based on ITS, $\operatorname{trn} \mathrm{L}-\mathrm{F}$, and $n d h \mathrm{~F}$ sequence data. Int J Plant Sci 166:1019-1028

Manns U, Anderberg AA (2007) Character evolution in Anagallis (Myrsinaceae) inferred from morphological and molecular data. Syst Bot 32:166-179

Martins L, Oberprieler C, Hellwig FH (2003) A phylogenetic analysis of Primulaceae s.l. based on internal transcribed spacer (ITS) DNA sequences data. Pl Syst Evol 237:75-85

Mast AR, Kelso S, Richards J, Lang DJ, Feller DMS, Conti E (2001) Phylogenetic relationships in Primula L. and related genera (Primulaceae) based on noncoding chloroplast DNA. Int J Plant Sci 162:1381-1400

Morozowska M, Czarna A (2006) Morfologia nasion i owoców Samolus valerandi L. (Primulaceae)—rzadkiego gatunku w Polsce. Rzadkie, ginące i reliktowe gatunki roślin i grzybów. Problemy zagrożenia i ochrony różnorodności flory polskiej. Mat. Ogólnopol. Konf. Nauk. Kraków 30-31 May 2006:109

Oh I-C, Anderberg AL, Schönenberger J, Anderberg AA (2008) Comparative seed morphology and character evolution in the genus Lysimachia (Myrsinaceae) and related taxa. Pl Syst Evol 271:177-197

Ståhl B, Anderberg AA (2004) Myrsinaceae. In: Kubitzki K (ed) The families and genera of vascular plants. VI Flowering plantsdicotyledons. Celastrales, Oxalidales, Rosales, Cornales, Ericales. Springer, Berlin, pp 266-281

Trift I, Källersjö M, Anderberg AA (2002) The monophly of Primula (Primulaceae) evaluated by analysis of sequences from chloroplast gene $r b c$ L. Syst Bot 27:396-407 